\title{
RIGHTS OF LIFE TENANTS AND REMAINDER- MEN IN CORPORATE DISTRIBUTIONS
}

\author{
By Hon. Alexander W. Smith, President of the Georgia Bar \\ Association.
}

For more than a century the courts of England and America have been evolving the relative rights of life tenants and remaindermen in distributions made to holders of corporate stocks. Ordinarily the question arises on devises of the income for life, with remainder in fee simple, and, pending termination of the life estate, the corporation issues new shares of stock in the form of a stock dividend distributable to the owners of record. In such case the question arises whether such new shares of stock go to the life tenant as part of the income or to the remaindermen as an addition to the corpus.

The earliest English cases adopted the rule that extraordinary dividends, whether in cash or stock, belonged to the remaindermen. (Brander v. Brander, 4 Ves. 800; Paris v. Paris, Io Ves. I85; Clayton v. Gresham, 1o Ves. 288; Witts v. Steeve, I3 Ves. 363 ; Irvin v. Houston, H. of L. Cas., vol. 2, p. 267 S. C. 4 Paton 52I). In Irvin v. Houston, 4 Paton 521, Lord Rosslyn, Lord Alvanley concurring, said that if an owner of bank stock "gives the life interest of his estate to any one, it can scarcely be his meaning that the life renter should run away with a bonus that may have been accumulating on the floating capital for half a century"; and that to take an account of the precise amount of profits which have accumulated before and after the commencement of the life interest in particular shares would lead to inconveniences which would be intolerable. 
In later cases extra dividends, declared as such (cash dividends), were held to go to the life tenant, but stock dividends to the remaindermen. (In re Barton's Trust, L. R. 5 Eq. 238; Price v. Anderson, I5 Sim. 473; Sproule v. Bouch, L. R. 29 Chan. Div. 635, 653, 659; Bouch v. Sproule, L. R. I2 App. Cas. 385). In Barton's Trust shares in a steam navigation company were settled by their owner upon trust to pay "the interest, dividends, shares of profits or annual proceeds," to a woman during her life, and after her death in trust for her children. The directors, acting within the scope of their authority, retained part of a half year's profits, and applied it to pay for new boats, and the company passed a resolution to issue to existing shareholders new shares representing the money so applied. It was argued that "the company had no power to compel the tenant for life to risk any more in the venture than the shares originally held, and could not be allowed for themselves by declaring or witholding a dividend out of the profits, to alter the rights as between tenant for life and remaindermen." But Vice-Chancellor Wood (afterwards Lord Chancellor Hatherley) held otherwise, and said: "As long as the company have the profits of the half year in their hands, it is for them to say what they will do with it, subject, of course, to the rule and regulations of the company". "The dividend to which a tenant for life is entitled is the dividend which the company chooses to declare. And when the company meet and say that they will not declare a dividend, but will carry over some portion of the half year's earning to the capital account, and turn it into capital, it is competent for them, I apprehend, to do so; and when this is done, everybody is bound by it, and the tenant for life of those shares cannot complain. The only mode in which a tenant for life could act would be to use his influence with his trustees as to their votes with reference to the proposed arrangement." "If a man has his shares placed in settlement, he gives his trustees, in whose name they stand, a power of voting, and he must use his influence to get them to vote as he wishes. But where the company, by a majority of their votes, have said that they will not divide this money, but turn it all into capital, capital it must be from that time. I think that this is the true principle, and I must hold that these additional shares form part of the capital fund under the settlement, and went to the children, and not to the tenant for life (their mother)." 
In the case of Cummings v. Bosivell (House of Lords) 2 Jur. N. S. 1005,1008 , decided in 1856 , the rule that extraordinary or unusual dividends declared during the life estate, whether stock or cash dividends, go to the corpus and not to the income, was recognized as the general rule in Scotland as well as in England, but was not applied in that case, because the first beneficiary was not a life renter, but an absolute fiar, though during his minority, before the expiration of which the bonus was declared, the income was payable to trustees for his benefit. (A "fiar" in the Scotch Law, is he whose property is burdened with a life rent. Bouvier.) (Preston v. Melville, I6 Sim. 163; Price v. Anderson, ${ }_{5}$ Sim. 473; Johnson a. Johnson, I5 Jus. 714). In the recent English case of Sproule v. Bouch, 29 Ch. D. 653; 12 App. Cas. 397, William Bouch bequeathed to his executor in trust for his widow for life, and after her death to the executor, shares in an iron company, whose directors had power, before recommending a dividend, to set apart out of the profits such sums as they thought proper as a reserved fund. Four years after the testator's death, the company, upon the recommendation of the directors, and out of a fund so reserved in the testator's lifetime, and of undivided profits, about half of which accrued before his death, made a bonus dividend, and an allotment of new shares, with liberty to each shareholder to apply the bonus dividend in payment for the new shares. Bouch's executor took the new shares and applied the bonus dividend in payment therefor. The House of Lords, reversing the judgment of the Court of Appeal, and restoring an order of Mr. Justice Kay, held that the corporation did not pay or intend to pay any sum as a dividend, but intended to and did appropriate the undivided profits as an increase of the capital stock; that the bonus dividend was therefore capital of the testator's estate, and the widow was not entitled either to the bonus or to the new shares.

So it will be seen that in none of the English cases was it ever held that a stock dividend, or division of surplus among stockholders, went to the life tenant, the general rule being that extraordinary or unusual dividends, whether in cash or stock, went to the remaindermen, but in some exceptional cases a cash dividend, larger than the usual dividend and declared in cash as a bonus, was held to belong to the life tenant.

The English rule is deduced as follows:

Ordinary dividends go to the life tenant; extraordinary dividends to the remainderman. 
While some of the commentators speak of an "American Rule" as distinguished from the English Rule, meaning thereby the rule first laid down by the Supreme Court of Pennsylvania in Earp's Appeal, such a designation is misleading. There are apparently many divergencies in the rulings of the American State courts, though a critical examination discloses that this divergence is more apparent than real.

The Massachusetts rule is thus stated in Minot $v$. Paine, 99 Mass. I08: "A simple rule is to regard cash dividends, however large, as income, and stock dividends, however made, as capital." Minot $v$. Paine has been followed consistently by the Supreme Court of Massachusetts. (A'dams v. Adams, I39 Mass. 449; $D^{\prime}{ }^{\prime} \circ g e$ v. Leeds, I76 Mass. 558; Hemenway v. Hemenway, I8I Mass. 406; Atkins v. Albree, I2 Allen, 359; Daland v. Williams, Ior Mass. $57 \mathrm{I}$; Leland v. Hayden, ro2 Mass. 542 ; Rand v. Hubbell, II 5 Mass. 46I ; Gifford v. Thompson, I I 5 Mass. 478; Lyman v. Pratt, 183 Mass. 58 ; Brozonell v. Anthony, I89 Mass. 442.)

The essential characteristic of a cash dividend is that it changes the title from the corporation to the stockholders, the assets of the company to the extent of the dividend being permanently and definitely reduced.

The essential characteristic of a stock dividend is that it transfers none of the corporate assets from the company to its stockholders; it does not change the amount of respective holdings in the company, but only dilutes the value of shares in exact proportion to the increase of their number. (Gibbons v. Mahon, I 36 U. S. 549; Mann v. Anderson, 106 Ga. 8I8; Williams v. W. U. Tel. Co., 93 N. Y. I89.)

In Hemenway $v$. Hemenway, I8I Mass. 406, the stockholders of a corporation accepted an offer to sell all of the stock, the sale, however, not to include certain "treasury assets", which were to be liquidated and distributed to the stockholders as an extraordinary dividend. A dividend was declared by the directors out of these assets as "representing accumulated and undivided profits of the company." Upon a bill for instructions by trustees under a will, to determine whether the dividend should be treated as capital or income, it was held that, the directors having treated the assets as income, as they might properly do, the entire dividend should be regarded as income. It was contended by the remaindermen that the real transaction was a transfer of the corporation by a sale of the stock, and that the distribution of the 
assets, though in form a dividend, was in reality a part of the consideration received for the stock, and should therefore be regarded as principal, and not income. The Court assumed that, if that were the real nature of the transaction, the contention that the dividend, so-called, was principal, and not income, would have been sound; but said that it saw no reason to doubt that the description of the dividend in the vote declaring it was a true one, or that the dividend was intended to be and was a dividend of profits.

In Adams v. Adams, 139 Mass. 449, the Court said that the many cases in which stock dividends have been declared to be capital, and dividends payable in money to be income, all proceed upon the ground that it is the declaration of the dividend which creates it as a dividend; and the form of the declaration, as shown by the action of the corporation construed in the usual way, determines the character of the dividend-whether it is a distribution of capital stock, or a division of profits.

In D'Ooge v. Leeds, 176 Mass. 558, the Court said, "The rule in Massachusetts is now well established. Everything is made to. turn upon the action of the corporation. 'A simple rule is to regard cash dividends, however large, as income, and stock dividends, however made, as capital.' (Citing Minot v. Paine, and other Massachusetts cases.) In considering the distribution to determine its character, substance, and not form, is regarded. The simple question in every case is whether the distribution made by the corporation is of money to be spent as income, or is of capital to be held as an investment in the corporation."

The Massachusetts rule is squared with the English rule by construing cash dividends to be ordinary dividends and stock dividends to be extraordinary dividends.

In Brinley v. Grou, 50 Conn. 66, the new shares went to the trustees as a part of the principal of the fund, and not to the children as part of the income. This case has been followed in Connecticut. (Spooner v. Phillips et al., Conn. I6 L. R. A. 46I; Boardinan v. Mansfield, 79 Conn. 634; Bulkley v. Worthington, \&c., Society, 78 Conn. 526; Smith v. Dana, 77 Conn. 543 ; Boardman v. Boardman, 78 Conn. 45I.)

In Green v. Bissell, 79 Conn. 547, the Court, in explaining the Massachusetts rule as applied to stock dividends, said: "The declaration of a stock dividend involves the creation and issue of new shares of stock. The basis of the issue, in so far as pay- 
ment into the corporation is not required of the recipient, is surplus assets, which thus become converted into strict capital with all which that implies. From the process there results an increase of both the number of outstanding shares and the amount of the corporate assets which have had that peculiar dedication to the corporate uses, which entitles them to the name of capital, strictly speaking."

Quoting from Smith v. Dana, 77 Conn. 543: "It is also one of the incidents of a stock dividend that the stockholder who receives his pro-rata proportion of a new issue, while he acquires the ownership of more shares, adds nothing to his proportionate ownership of the assets of the corporation. His holding after the new issue bears precisely the same ratio to the total of the outstanding shares of the corporation as did his previous holding to the previous total." The Connecticut Court seems to lay down the doctrine that it is universally true that surplus earnings do not, as to stockholders, partake of the character of income until they are declared as dividends; and whether they will ever be so declared is a matter of uncertainty, since, speaking generally, they may, in the discretion of the directors, although not capitalized, be for. ever retained in the corporation to serve as a part of its working capital. In this state and elsewhere it is only to surplus earnings declared in cash that the character of income attaches, and through the medium of stock dividends they may go to capital, and permanently insure to the benefit of that interest.

The Massachusetts rule giving stock dividends to the corpus was applied in re Brozen, I4 R. I. 37I, where stock dividends were declared from surplus, without inquiring as to the time when the surplus was earned.

In Richardson v. Richardson, $75 \mathrm{Me}$. 570, the Court says: "The decided preponderance of authority probably conceded the point that dividends of stock go to the capital, under all ordinary circumstances. But we are well convinced that the general rule, deducible from the latest and wisest decisions, declared all money dividends to be profit or income, belonging to the tenant for life, including not only the usual annual dividend, but all extra dividends or bonuses payable in cash from the earnings of the company". . . . "We think the true rule to be that when a dividend upon stock is declared by a corporation it belongs to the person holding the stock at the time, whether the holder be a life tenant or remainderman, without regard to the source from which 
or the time during which the profits and earnings divided were acquired by the company."

Some of the strongest cases following the Massachusetts rule have been decisions of the Supreme Court of Illinois. (Billings et al v. Warren, 2x6 Ills. 28x; Bluin v. Gillett, 208 Ills. 473; DeKoven et al, trustee, v. Alsop, et al, 205 Ills. 309.) The DeKoven-Alsop case holds that extraordinary cash dividends on stock owned by the testator, declared after his death, though earned during his life, were payable to the life tenant as income; that stock dividends declared after the death of the testator, who had devised his stock in trust to pay the income to the life tenant and the principal to a remainderman, were to be held for the benefit of the remainderman, whether the earnings which they represented accrued before or after the death of the testator.

The Pennsylvania rule ignores the character of the dividend as the criterion of the rights of the parties, but inquires as to the time, relative to the inception of the life estate, covered by the accumulation of earnings from which the extraordinary dividends were declared, and, if it ascertains that the entire fund accumulated before the inception of the life estate, awards the entire dividend, whether stock or cash, to the corpus; and if the entire fund accumulated after the inception, and during the continuance of the life estate, awards the entire dividend to income; and if the fund accumulated partly before and partly after the inception of the life estate, apportions the dividend, whether stock or cash, between the life tenant and the remainderman. The first case in which the Pennsylvania rule was clearly announced was Earp's Appeal, $28 \mathrm{~Pa} .368$.

South Carolina is sometimes quoted as in line with the Pennsylvania rule citing $C o b b$ v. Fant, $36 \mathrm{~S}$. C. I, but it is not a precedent, because it is decided on the peculiar language of the trust deed involved in the case.

The dictum in Earp's Appeal is at variance with the language of the same court in Moss' Appeal, $83 \mathrm{~Pa} .268$, and was expressly disapproved in Connolly's Estate, $198 \mathrm{~Pa}$. 137 . The Pennsylvania rule seems to have been followed, substantially, in New Hampshire (Holbrook v. Holbrook, 74 N. H. 20I), in Maryland (Thomas v. Gregg, $78 \mathrm{Md}$. 545) and in New Jersey (Lang v. Lang, 57 N. J. Eq. 325). 
The Kentucky rule disregards the character of the dividend as a criterion by which the respective rights of life tenant and remainderman are determined. It takes no account of the time relative to the inception of the life estate covered by the accumulation of the earnings out of which the dividend is declared, and repudiates the principle of apportionment. Thus, the Court, in Hite v. Hite, $93 \mathrm{Ky} .257$, held that a stock dividend representing earnings made by the corporation was income belonging to the life tenant, the settled rule being that dividends, whether stock or cash, are non-apportionable, and must be considered as accruing as of the date declared; and that, if the life tenancy has begun when a cash dividend is declared, it belongs to the life tenant, although it results in part from profits previously earned, and goes to him irrespective of the time when it is earned.

Properly understood, the New York rule follows the action of the corporation in distributing the stock. It differs from Pennsylvania and coincides with Kentucky in that it repudiates apportionment, and from the Massachusetts rule in that a stock dividend may go to the life tenant if the corporate action declaring it makes it a distribution of earnings rather than a capitalization of surplus.

Chester v. Buffalo Car Mfg. Co., 70 App. Div. 443, is based upon two general propositions: (I) That a corporation with a surplus of accumulated profits within the limits of good faith has the power either to distribute it as dividends, or to retain it and convert it into capital; (2) that the substance and intent of the action of the company, as evidenced by its treatment of the surplus, and its resolutions in issuing new stock against it, will be considered by, if they will not control, the courts, in deciding whether such issue is dividend, and hence income belonging to the life tenant or not; that, if the company pays money, or issues stock, as a distribution of the profits, it will ordinarily go to the life tenant; but if it issues stock as capital, and appropriates its surplus as an increase of the capital stock of the concern, such issue will be held to inure to the benefit of the remainderman.

The Iowa rule may be taken from Kalbach $v$. Clark, I33 Ia. 215, from which the following quotation is made: "We shall not attempt to review the cases cited in support of the different rules. He who cares to know the logic thereof may read. Our duty is performed when we establish a rule for this State which we believe is best sustained on principle and by authority. That rule 
more nearly approximates what is called the American than any other. Under it, we start with the notion that all pure dividends, whether in cash, or stock, or other property, are a part of the income, and, when declared, should go to the life tenant and not to the remainderman, as it is not a part of the corpus of the property, but a part of the income derived from the use and management thereof. Any dividends, so-called, presumptively belong to the life tenant, as they are, in the absence of a showing to the contrary, assumed to have been divided as profits. If, however, the so-called stock dividends represent the corporate capital-that is, represent nothing but the natural growth or increase in the value of the permanent property, so that there is merely a change in the form of ownership-such stock should go to the remainderman; for in such cases the dividend is a dividend of capital, representing simply an increase in the value of the physical property, good will, or other thing of tangible value."

The rule in Georgia is fixed by the Code, as follows: "The natural increase of the property belongs to the tenant for life. Any extraordinary accumulation of the corpus-such as the issue of new stock upon the share of an incorporated or joint-stock company-attaches to the corpus and goes with it to the remainderman." Code of I910, Sec. No. 3667 , recently construed in Jackson v. Maddox, 7o S. E. Rep. 865.

The leading case in Tennessee is Pritchett $v$. Nashville Trust Co., 96 Tenn. 472. A life tenant is entitled to stock dividends declared from net earnings made after the respective rights of the life tenant and remaindermen have attached to corporate stock bequeathed to them. This case obliterates all distinction between cash dividends and stock dividends, ordinary dividends and extraordinary dividends, and capitalization of earnings. In this respect it antagonizes the Massachusetts rule and follows Pennsylvania. The question of apportionment was not involved. The case, however, turns on the resolutions under which these "dividends" were declared.

On Feb. 16, 1907, the Supreme Court of Tennessee decided the case of $T u b b v$. Fowoler, et al, $99 \mathrm{~S}$. W. Rep. 988. There the life tenant sought to force the executor to sell the stock, restoring its par value to the trust and paying to her the excess brought by reason of its share in the surplus and undivided profits, claiming the same, on the ground that it belonged to her as "income." The Court says: "Where a widow was entitled under her husband's 
will to the income of bank stock, the portion of surplus and undivided profits held by the banks apportionable to the shares could not be regarded as 'income." "

The Supreme Court of the United States had occasion to consider the question in Gibbons v. Mahon, 136 U. S. 549, and in a lucid and convincing opinion enunciated what should rightfully be known as the "American Rule" on the subject. In the course of the opinion the Court said:

"The distinction between the title of a corporation, and the interest of its members or stockholders, in the property of the corporation, is familiar and well settled. The ownership of the property is in the corporation, and not in the holders of shares of stock. The interest of each stockholder consists in the right to a proportionate part of its property whenever dividends are declared by the corporation, during its existence under its charter, and to a like proportion of the property remaining upon the termination or dissolution of the corporation after payment of its debts. Van Allen v. Assessors, 3 Wall. 573, 584; Delaware Railroad Tax, I8 Wall. 206-230; Tennessee v. Whitworth, II7 U. S. 129, I36; New Orleans v. Houston, II9 U. S. 265-277.

"Reserved and accumulated earnings, so long as they are held and invested by the corporation, being part of its corporate property, it follows that the interest therein, represented by each share, is capital, and not income, of that share, as between the tenant for life and the remainderman, legal or equitable thereof.

"Whether the gains and profits of a corporation should be so invested and apportioned as to increase the value of each share of stock, for the benefit of all persons interested in it, either for a term of life or of years, or by way of remainder in fee; or should be distributed and paid out as income, to the tenant for life or for years, excluding the remainderman from any participation therein, is a question to be determined by the action of the corporation itself, at such times and in such manner as the fair and honest administration of its whole property and business may require and permit, and by a rule applicable to all holders of like shares of its stock; and cannot, without producing great embarassment and inconvenience, be left open to be tried and determined by the courts as often as it may be litigated between persons claiming successive interests under a trust created by the will of a single shareholder, and by a distinct and separate investigation, through a master in chancery or otherwise, of the affairs and 
accounts of the corporation, as of the dates when the provisions of the will of that shareholder take effect, and with regard to his shares only.

"A stock dividend really takes nothing from the property of the corporation, and adds nothing to the interest of the shareholders. Its property is not diminished and their interests are not increased. After such a dividend as before, the corporation has the title in all the corporate property; the aggregate interests therein of all the shareholders are represented by the whole number of shares; and the proportional interest of each shareholder remains the same. The only change is in the evidence which represents that interest, the new shares and the original shares together representing the same proportional interest that the original shares represented before the issue of new ones."

Whatever of confusion is noticeable in the decisions of the Courts may be traced to their failure always to bear in mind that the stockholder has no title to the assets of his corporation. The corporation, as a separate entity and a legally living person, not only owns its assets, but, within the bounds of good faith and in the exercise of business discretion ascertained and expressed through the media of its charter and by-laws, has absolute power to dictate whether they shall be permanently capitalized or periodically distributed. If a minority only short of a majority is without power to control such action, much less can a single stockholder through the instrumentality of his will effect such a result.

It is a fallacy to argue that surplus is income because derived from earnings which should have been paid out to stockholders as earned, and that when finally transformed into capital stock, eo nomine, the certificates representing it should be treated as income and turned over to the stockholders. The fallacy of this argument is fundamental. Surplus is never anything but capital. Year by year, as the directors take under consideration the declaration of dividends, they must ascertain whether the business of the corporation is increasing-the earnings increasing - the investments increasing, - and they may find everything increasing except the capital stock. If it is a healthful and successful corporation, they will inevitably find these things. If all the earnings are segregated, reduced to cash, paid out as made, the increase bulging out on every side must stop. The surplus would never accumulate, and for the best of all reasons-it would not be earned. One cannot eat a cake and have it, too. 
The outcome of the cases in the Supreme Court of the United States, and of New York, Illinois and some of the other states, is that the solution of the question is crystallized in the action of the corporation. If the object in view is to decrease the assets - of the corporation by paying out a portion of the same in distributable form, the corporate action should be the declaration of a dividend with a provision for its disbursement without reservation. Then it becomes income to the stockholder and goes to the life tenant. If on the other hand the object is to retain title to all the assets of the corporation and merely change the representative muniments of interest therein, such as the conversion of surplus into permanent capital, the corporate action should clearly indicate such purpose and the courts will have no difficulty in carrying out such a bona fide intention.

One or two practical suggestions in conclusion. When advising a corporation as to capitalizing surplus or issuing stock dividends, it would be well to ascertain whether or not any of its stock is held for account of life tenants and remaindermen, examine the instrument creating the dual estate, and make the corporate action, in good faith, do justice to both interests. When advising a testator desiring to bequeath corporate stocks to one for life and another in remainder, let the will specifically define income to mean only such distributions to the shares involved as are payable out of, and serve to decrease, the assets of the corporation in the form of distributable and absolute dividends, and prescribe that all stock dividends, or other form of increasing the number of shares without disturbing the title of the corporation to all of its assets, shall go to the remainder as a part of the corpus.

Atlanta, Ga., I9ri. Alex. W. Smith. 